\author{
Ewa Polak, Waldemar Polak \\ Uniwersytet Gdański \\ e-mail: polakewa@wp.pl
}

\title{
WSPÓŁCZESNE UWARUNKOWANIA POLITYKI GOSPODARCZEJ
}

\section{THE INFLUENCE OF GLOBALIZATION PROCESSES ON THE ECONOMIC POLICY OF THE STATE}

DOI: $10.15611 /$ pn.2017.498.24

JEL Classification: F62, F68, F23

Streszczenie: W ostatnich latach rośnie znaczenie międzynarodowych organizacji gospodarczych. Nadają one ton i kierunek nie tylko przemianom ekonomicznym, ale i politycznym, społecznym i kulturowym. Wpływają na kondycję ekonomiczną państw. Stopniowo przejmują globalną władzę. Przynależność do tych organizacji oraz zainteresowanie kapitału ponadnarodowego określonym państwem uwiarygodnia, nobilituje i włącza kraje do światowego systemu gospodarczego. Dla krajów biedniejszych wiąże się to z możliwością uzyskania zwrotnej lub bezzwrotnej pomocy, dostępu do postępu technicznego lub dopływu kapitału produkcyjnego. Okupione jest to jednak koniecznością akceptacji ujednoliconej neoliberalnej polityki gospodarczej, ograniczeniem suwerenności i rezygnacją z części swoich kompetencji, a nawet interesów. Celem podjętych badań jest analiza głównych uwarunkowań współczesnej polityki gospodarczej i kierunków jej zmian oraz skutków oddziaływań procesów i sił globalnych na decyzje podejmowane w gospodarce.

Słowa kluczowe: globalizacja, polityka gospodarcza, gospodarka globalna.

Summary: The work is devoted to the analysis of the impact of international economic organizations and large transnational companies on the policy and the condition of the state and its citizens. They are becoming the dominant players in the international arena. These economic actors are putting ever-increasing demands to the state, they are forcing into implementing solutions favourable to themselves and they are taking over some of the state functions. Because of the transnational and often even intercontinental range of their activities, there is no comparable economic power. Its global economic power transforms into political and socio-cultural influence. The international economic organizations are limiting the sovereignty of the state, especially in those areas where government policy comes into conflict with the interests of capital. The growing impact of the international capital can provide both opportunities and challenges and threats to the functioning of the state and its security.

Keywords: globalization, economic policy, global economy. 


\section{Wstęp}

Zachodzące współcześnie procesy globalizacji związane są ze wzrostem zasięgu, zakresu, szybkości, różnorodności, intensywności, gęstości i siły wzajemnych wpływów, oddziaływań i zależności na skalę ponadregionalną. Kojarzy się je z usuwaniem barier oraz coraz większą swobodą przepływu przez granicę towarów usług, kapitału produkcyjnego i spekulacyjnego, ludzi, dóbr kulturowych i technologii, a także patologii społecznych i przestępczości. W ich efekcie powstaje nowy porządek światowy, w którym, obok państw, pojawiają się nowe podmioty prawnomiędzynarodowe, nowe ośrodki decyzyjne oraz dochodzi do olbrzymiej koncentracji i jednocześnie rozproszenia władzy. Następuje transnacjonalizacja norm prawa i transfer wzorców. Globalizacja wpływa na zmianę polityki gospodarczej państw oraz znaczne jej ujednolicenie. Celem podjętej analizy jest ustalenie głównych zewnętrznych uwarunkowań współczesnej polityki gospodarczej oraz kierunków jej zmian i konsekwencji oddziaływań procesów i sił globalnych na podejmowane decyzje i działania w gospodarce. W niniejszym poznaniu dużo uwagi poświęcono badaniu problemu nadawczego na podstawie analizy specjalistycznych raportów i doniesień prasowych. Analizowano wiadomości na temat oddziaływań i skutków globalizacji w sferze polityki gospodarczej, a także sposób komentowania aktualnie zachodzących procesów i wydarzeń zarówno przez uczonych, jak również dziennikarzy i polityków. Tego typu informacje były sukcesywnie gromadzone na potrzeby niniejszej pracy.

W rozwiązaniu problemu badawczego przyjęto następujące metody i techniki badawcze: analizę literatury przedmiotu, doniesień prasowych, specjalistycznych raportów, danych statystycznych, metodę porównawczą, metodę systemową, wnioskowanie przez analogię, bezpośrednią obserwację rzeczywistości. Wykorzystano również metodę polegającą na syntetyzowaniu rozproszonych informacji i obserwacji oraz formułowaniu na tej podstawie określonych wniosków opartych na zasadach analizy logicznej i dedukcji.

Ze względu na wymagania dotyczące rozmiarów niniejszego artykułu i obszerność prezentowanej tematyki, w niewielkim stopniu odniesiono się w nim do istniejących teorii na temat zależności pomiędzy globalizacją a polityką gospodarczą ${ }^{1}$.

Generalnie linia podziału w zakresie poglądów na temat konsekwencji procesów globalizacji dla polityki gospodarczej państwa przebiega zgodnie ze stanowiskami ich autorów wobec rozwiązań neoliberalnych.

\footnotetext{
${ }^{1}$ Patrz (subiektywny wybór autora) np.: J.E. Stiglitz, I. Wallerstein, B.R. Chomsky, B.R. Barber, D. Rodrik, A. Lindbeck, M.E. Porter, K. Ohmae, R.G. Lipsey, R. Heibroner, M. Ramesh, , J. Manzi, C. Hay, W. Drezner, A. Tonelson, G. Stigler, N. Peltz, J. Sachs, G. Sorman, A. Giddens, G. Soros, L.C. Thurow, M. Olson.
} 


\section{Gospodarka globalna}

Na całościowy system światowy składa się sieć gospodarek narodowych, globalnych i regionalnych organizacji międzynarodowych, korporacji ponadnarodowych, rynków, podmiotów gospodarczych działających wewnątrz państw oraz państwowe i międzynarodowe regulacje prawne i relacje współzależności, dominacji i podporządkowania. Globalny system ekonomiczny stanowi nową jakość, zmienia bowiem warunki i charakter działania oraz rolę i możliwości poszczególnych jego elementów. Funkcjonowanie jego części składowych można zrozumieć jedynie w kontekście dynamiki całości. Wzrasta w nim znaczenie niepaństwowych, eksterytorialnych podmiotów stosunków międzynarodowych (np. korporacje ponadnarodowe) oraz grupy państw tworzących tzw. centrum gospodarki światowej ze Stanami Zjednoczonymi Ameryki na czele. Zasady jego funkcjonowania i związane z tym regulacje wynikają nie $z$ demokratycznych procedur, ustaleń $\mathrm{i}$ kontroli, ale z gry sił i interesów ekonomicznych na globalnym rynku. Niezbędnym warunkiem jego istnienia jest deregulacja funkcji państwa i jego przychylność dla sił ponadnarodowych.

„Jesteśmy świadkami - jak stwierdza R. Kuźniar - swoistej dezagregacji państwa (...). Państwo zaczyna podlegać fragmentacji, a jego poszczególne segmenty stają się częścią różnych reżimów (systemów regulacji) międzynarodowych, zarówno regionalnych, jak i uniwersalnych: handlowych, finansowych, inwestycyjnych, ochrony środowiska, spraw socjalnych, praw człowieka, w sferze bezpieczeństwa itp. Wpływy i nacisk, jakim podlegają współczesne władze państwowe, mają charakter zarówno formalny, jak i nieformalny; legalny i nielegalny. Powstają ponadnarodowe struktury regulacyjne. To wszystko nie układa się w jedną całość, lecz rządzi się swymi własnymi prawami, obowiązkami, współzależnościami i zależnościami, siłami o różnych wektorach, które »rozrywają« całość zwaną państwem w różnych kierunkach" [Haliżak, Kuźniar, Simonides (red.) 2003, s. 157]. Kształtujący się ład międzynarodowy ma charakter hybrydowy.

Następuje erozja suwerenności państwowej, prymat zobowiązań (w tym finansowych) i interesów międzynarodowych przed zobowiązaniami wobec społeczeństwa, coraz mniejsze możliwości rządów, mniejsza skuteczność i czytelność polityki. W konsekwencji obserwuje się osłabienie struktur państwowych, ograniczenie funkcji sprawowanych przez państwo i rozczarowanie do jego instytucji oraz mechanizmów demokratycznych. Skutki interwencjonizmu państwowego redukuje też rosnąca mobilność zasobów.

- Gospodarka nabrała wymiaru globalnego i stała się mniej stabilna i przewidywalna. Państwa są wrażliwsze na wydarzenia, naciski i opinie zewnętrzne. Coraz częściej dochodzi do kryzysów finansowych o wymiarze globalnym. Następuje wirtualizacja wartości i wskaźników ekonomicznych. Realna i wirtualna gospodarka stały się niezależnymi od siebie bytami.

- Trudno jednoznacznie odpowiedzieć na pytanie o zmiany w zakresie regulacji prawnych w sferze społeczno-gospodarczej. Generalnie maleje liczba regulacji 
ograniczających swobodę przepływu kapitału ponadnarodowego i prowadzenia przez niego działalności gospodarczej. Maleje też prawna ochrona społeczeństwa (przepisy prawa pracy, opieka socjalna itp.). W literaturze można w związku z tym spotkać stwierdzenie o protekcjonizmie dla bogatych i liberalizmie dla biednych. Rośnie natomiast liczba regulacji prawnomiędzynarodowych, w tym ułatwień i preferencji dla bezpośrednich inwestycji zagranicznych (BIZ), oraz regulacji dotyczących kontroli zachowań społecznych (z powodu/pod pretekstem zagrożeń terrorystycznych).

\section{Rola międzynarodowych organizacji gospodarczych}

We współczesnym świecie dominują niepaństwowe, potężne trans- lub międzynarodowe podmioty gospodarcze; obserwuje się koncentrację bogactwa i wertykalizację władzy. W dużym stopniu podporządkowały sobie one państwa i uzależniły je od siebie [Rothkopf 2009]. Są to przede wszystkim potężne przedsiębiorstwa ponadnarodowe, globalne i ponadregionalne organizacje gospodarcze (MFW, BŚ, WTO), regionalne organizacje gospodarcze (np. UE, MERCOSUR, ASEAN/AEC, NAFTA, ABII), tzw. fundusze spekulacyjne, inne instytucje związane $z$ finansami, instytucje służące kształtowaniu opinii publicznej oraz międzynarodowe sądownictwo.

Pewne ujednolicenie polityki państw wynika z przyjętych zobowiązań międzynarodowych i z obowiązującej zasady prymatu prawa międzynarodowego nad regulacjami wewnętrznymi. Organizacje międzynarodowe uzależniają decyzje o przynależności do nich lub możliwości uzyskania pomocy od przeprowadzenia konkretnych, głównie prorynkowych i liberalizujących gospodarkę, reform [Michałowski 2008, s. 185]. Posiadają przy tym liczne narzędzia wywierania wpływu na pożądane zachowania władz państwowych - oceny „ekspertów”, ograniczanie lub odmowa pomocy, odmowa restrukturyzacji zadłużenia, sankcje ekonomiczne, kary finansowe, zawieszenie w prawach członka organizacji, ostracyzm i izolację, kształtowanie międzynarodowej tzw. opinii publicznej, materialne i niematerialne gratyfikacje dla polityków.

W MFW każde państwo posiada swojego eksperta, który kontroluje prowadzoną przez rządy politykę gospodarczą i jej efekty. Wszystkie kraje podlegają corocznemu audytowi. Organizacja ta jest instytucją publiczną utworzoną z pieniędzy podatników, ale nie reprezentowaną i kontrolowaną przez nich. MFW i BŚ w ramach programów dostosowawczych nakłaniają m.in. do rezygnacji z subwencjonowania żywności i paliwa oraz do ograniczenia wydatków i prywatyzację sektora publicznego oraz zaopatrzenia w wodę, co wpływa na drastyczne pogorszenie jakości ży$\mathrm{cia}^{2}$. Zakres warunkowości MFW systematycznie zwiększał się od 2 do 3 warunków w latach osiemdziesiątych, do kilkunastu, a nawet kilkudziesięciu na początku XXI

${ }^{2}$ Na początku lat dziewięćdziesiątych XX w. zagraniczni doradcy otrzymali w Polsce około 4,5 mld zł za wskazanie, komu sprzedać polskie przedsiębiorstwa. 
wieku, co coraz częściej wywołuje zarzuty przekroczenia przez MFW statutowych kompetencji i ograniczania suwerenności gospodarczej państw³

\section{Neoliberalne przewartościowanie zasad polityki gospodarczej}

Globalne i regionalne organizacje gospodarcze narzucają państwom określony kierunek reform kojarzony z neoliberalizmem i tzw. Waszyngtońskim Konsensusem. Zalecenia tego Konsensusu, bez względu na sytuacje i problemy poszczególnych państw, sprowadzają się do: ograniczenia interwencjonizmu państwowego, uwolnienia cen i płac, upłynnienia kursu walutowego, urynkowienia sektora publicznego, prywatyzacji, ograniczenia budżetowej redystrybucji dochodu narodowego, deregulacji rynku pracy, antyinflacyjnej, restrykcyjnej polityki gospodarczej, otwarcia granic na zagraniczne towary, usługi i kapitał.

Neoliberałowie dokonali przewartościowania w zasadach polityki gospodarczej. Uznali, że rzeczywisty dochód narodowy zależy nie od popytu rynkowego, ale od zasobów czynników produkcji (przede wszystkim od kapitału), od efektywności ich wykorzystania oraz opłacalności produkcji. Nierównowaga związana z rosnącym popytem jest, według nich, niwelowana wzrostem cen, a nie produkcji. Rosnący popyt skutkuje wzrostem cen i powoduje spadek dochodu narodowego z powodu wzrostu popytu na pieniądz i w konsekwencji wzrost stóp procentowych. Efektywność polityki gospodarczej oceniają według kryterium równowagi budżetu i rachunku bieżącego, stopnia prywatyzacji, otwartości i liberalizacji gospodarczej oraz jej atrakcyjności dla inwestorów. Państwo, według neoliberałów, narusza naturalną równowagę w gospodarce i osłabia motywacje do aktywności na rynku. Jeżeli jednak przyjmie się, że ingerencja państwa w sferę gospodarczo-społeczną może mieć charakter proprodukcyjny lub prospołeczny i występować może w postaci preferencji lub ograniczeń, to neoliberałowie przez wolność gospodarczą rozumieją sytuację, kiedy państwo z jednej strony wykorzystuje narzędzia interwencjonizmu proprodukcyjnego w postaci preferencji, przywilejów i specjalnej ochrony dla kapitału, a z drugiej poszerza obszar ograniczeń wobec społeczeństwa i polityki społecznej.

Promowana między innymi przez kapitał neoliberalna filozofia związana jest z podejściem mikroekonomicznym i myśleniem propodażowym [Szymański 2007].

\footnotetext{
${ }^{3}$ Np. w 2011 r. MFW pożyczył Portugalii 78 mld euro w zamian za zgodę na radykalną podwyżkę podatków i głębokie cięcia wydatków socjalnych. Polska z kolei została skłoniona w 2009 r. do otwarcia tzw. elastycznej linii kredytowej w wysokości 30 mld euro (z której nie korzystała), za co musiała płacić MFW ponad $200 \mathrm{mln}$ zł rocznie i jednocześnie zgodziła się na pożyczenie Funduszowi kwoty 6,27 mld euro na dofinansowanie zachodnich banków w czasie trwania kryzysu. BŚ w ramach narzuconego programu restrukturyzacyjnego skłonił polski rząd do likwidacji części kopalń; sposób, w jaki to zrobić podsunęła Polsce Roland Berger Strategy Consultants, największa niemiecka firma doradcza (http://wpolityce.pl/gospodarka/230591 (10.06.2017)). Rumunia w 2013 r., w zamian za pomoc kredytową MFW, zgodziła się wprowadzić opłaty za pobyt pacjentów w szpitalu (http://www.rynekzdrowia.pl/Finanse-i-zarzadzanie/Rumunia-rzad-wprowadzi-oplaty-za-pobyt-w-szpitalu,127510,1.html $(8.05 .2017))$.
} 
Zatrudnienie i płace rozpatruje się tu głównie w kategoriach kosztów (które należy ograniczać), a nie w kategoriach pobudzania popytu, społecznej sprawiedliwości i społecznego dobrobytu. Srodkiem pobudzania popytu są: promocja, reklama, kreowanie nowych wzorców kulturowych i stylów życia oraz coraz łatwiejszy dostęp do kredytów i ratalnych form sprzedaży, a nie wzrost dochodów osobistych. Pojawiła się sprzeczność między makroekonomicznymi interesami państwa a mikroekonomicznym interesem firmy, która chce zminimalizować koszty i przerzucić jak największą ich część na otoczenie oraz uzyskać jak największe zyski i przywileje od państwa, wzmacniające jej pozycję konkurencyjną ${ }^{4}$ Jednak racjonalność mikroekonomiczna, bez narzucania warunków brzegowych przez państwo, stoi w sprzeczności z racjonalnością makroekonomiczną.

Racjonalność mikroekonomiczna narzucona też została tak nierynkowym dziedzinom życia, jak ochrona zdrowia, kultura, edukacja, zaopatrzenie w wodę, opieka nad ludźmi starymi i przewlekle chorymi. Instytucje działające w szeroko rozumianej sferze polityki społecznej rozliczane są nie ze swojej społecznej skuteczności, ale z ekonomicznej efektywności. Lansuje się powszechnie pogląd o konieczności sprywatyzowania sektora usług publicznych w celu zwiększenia efektywności jego działania [Polak 2009]. Państwo zwalnia się od odpowiedzialności za funkcjonowanie sfery usług społecznych i ogranicza na ten cel wydatki budżetowe, które mogą być przeznaczone na dalsze zwiększanie globalnej konkurencyjności (odwracanie strumienia redystrybucji) prywatnych producentów gospodarczych.

Rządy mają do swojej dyspozycji coraz mniej instrumentów, za pomocą których mogą oddziaływać na sferę społeczno-gospodarczą, a ich polityka jest coraz mniej skuteczna. Obserwuje się więc coraz mniejszy wpływ państwa na gospodarkę, kondycję i bezpieczeństwo ekonomiczne obywateli, przepływ informacji, pieniędzy, dóbr i usług, rozwój naukowo-techniczny i kulturalny.

\section{Miejsce kapitału ponadnarodowego we współczesnym ladzie globalnym}

Do głównych sił globalnych, obok międzynarodowych organizacji gospodarczych, zalicza się produkcyjny i spekulacyjny kapitał ponadnarodowy, który staje się coraz bardziej mobilny, eksterytorialny, płynny, lekki i jednocześnie roszczeniowy. Obroty, ale też dochody wielu korporacji ponadnarodowych przekraczają PKB średnio zamożnych krajów. Kapitał ponadnarodowy korzysta z coraz większych przywilejów i ma ambicje stać się nie tylko władzą ekonomiczną, ale również polityczną i kulturową̧5.

\footnotetext{
${ }^{4}$ Np. General Electric w 2011 r. odnotowała zysk w wysokości 14 mld USD i nie zapłaciła jednocześnie żadnego podatku dochodowego.

${ }^{5}$ Badacze ze szwajcarskiego Federalnego Instytutu Technologii w Zurychu policzyli, że 147 korporacji dysponuje większą siłą niż państwa, a mniej niż 1\% korporacji kontroluje $40 \%$ globalnej sieci [Janik 2013].
} 
Coraz częściej politycy stają się też zakładnikami i marionetkami w rękach wielkiego kapitału. Obowiązuje zasada obrotowych drzwi - zmiana kadry na wysokich stanowiskach pomiędzy światem polityki i sektorem finansów [Buchter 2009]. O skali problemu świadczyć może tytuł artykułu w jednej z amerykańskich gazet w 2012r.: CitiGroupzastępujeJ.P. MorgannastanowiskuszefapersoneluBiatego Domu. J. Stiglitz stwierdził natomiast: „Ludzie idą z Wall Street do rządu, a potem wracają na Wall Street. W ten sposób wypracowują wspólny światopogląd, który hamuje skuteczną reformę systemu finansowego. (...) Goldman Sachs przez swoich ludzi od lat kontroluje Biały Dom (...)" [Stiglitz 2007, s. 203].

A. Podgórecki zjawisko niejawnych powiązań pomiędzy światem polityki i biznesu nazywa „brudnymi wspólnotami”, w których politycy mają „związane ręce” ze względu na swoje uwikłania i zależności [Podgórecki 1969]. Silne grupy nacisku w sposób formalny lub nieformalny mogą w znacznym stopniu wpływać na decyzje rządzących partii. System, w którym występują silne powiązania między światem biznesu i polityki, polegające na wzajemnym świadczeniu usług, nazywa się kapitalizmem politycznym lub klientystycznym.

Wielgosz uważa w związku z tym, że podstawą globalizacji we współczesnym świecie jest liberalizm dla biednych, a protekcjonizm dla bogatych i transfer pieniędzy od biednych do bogatych [Wielgosz 2004, s. 111]. Sytuacja gospodarcza państw i poszczególnych ludzi została uzależniona od działań i decyzji, na które nie mają oni wpływu.

Tabela 1. Państwowe regulacje w krajach rozwijających się dotyczące BIZ w latach 1991-2010

\begin{tabular}{|c|c|c|c|}
\hline Lata & $\begin{array}{c}\text { Liczba regulacji } \\
\text { korzystnych dla BIZ }\end{array}$ & $\begin{array}{c}\text { Liczba regulacji } \\
\text { mniej korzystnych dla BIZ }\end{array}$ & $\begin{array}{c}\text { Liczba państw, które } \\
\text { wprowadziły regulacje } \\
\text { w swoim prawodawstwie }\end{array}$ \\
\hline 1991 & 80 & 2 & 38 \\
\hline 1995 & 101 & 1 & 59 \\
\hline 1999 & 106 & 6 & 62 \\
\hline 2003 & 135 & 16 & 78 \\
\hline 2006 & 131 & 9 & 62 \\
\hline 2010 & 147 & 3 & 65 \\
\hline
\end{tabular}

Źródło: [UNCTAD 2001; Hay 2005; UNCTAD 2011].

Konsekwencją nacisków wywieranych na państwo jest coraz przyjaźniejsza dla dużych przedsiębiorstw polityka gospodarcza, czego przykłady zaprezentowano w tabeli 1 . W niemal wszystkich krajach obniżeniu ulegają też stawki CIT i najwyższe stawki PIT.

Kierunek dalszych zmian w zakresie władzy ekonomicznej pokazują negocjowane w ostatnim okresie umowy pomiędzy USA i Kanadą a innymi krajami, oficjalnie w sprawie wolnego handlu, a w rzeczywistości prowadzące do wzrostu dominacji 
krajów najwyżej rozwiniętych i pochodzącego z nich kapitału. Są one negocjowane z pominięciem udziału przedstawicieli społeczeństwa i mają charakter niejawny. Według „The Guardian”, około 92\% uczestników negocjacji to lobbyści korporacyj$\mathrm{ni}^{6}$. Negocjacje dotyczą wielu sfer życia, a ich realizacja prowadzi do zmian w relacjach pomiędzy sferą biznesu, światem polityki a społeczeństwem, jest zagrożeniem dla funkcjonowania państwa i demokracji. Ważnym ich elementem jest zniesienie instrumentów ochrony rynku o charakterze parataryfowym i pozataryfowym. Jeżeli chodzi o umowy CETA, TTIP i TIP, najwięcej obaw budzi zapis o trybunałach inwestycyjnych, przed którymi przedsiębiorstwa (tylko zagraniczne) mogą zaskarżyć każdą decyzję państw, z pominięciem oficjalnych dróg legislacyjnych. Powodem do zaskarżenia może być każda sytuacja, w której korporacja uzna, że przepisy państwa godzą w jej interes. Może to być np. zaskarżona przez korporację w Egipcie płaca minimalna, zakwestionowane przez korporacje amerykańskie w Meksyku przepisy ekologiczne, zaskarżona przez koncern tytoniowy Philip Morris informacja o szkodliwości palenia umieszczona na opakowaniu papierosów. Państwa mogą się jedynie bronić ${ }^{7}$. Trybunały mają charakter prywatny, a postępowania przed sądem arbitrażowym, jego przebieg i rezultaty mogą mieć charakter tajny, aby obywatele nie mogli się dowiedzieć, jakie kwoty pieniędzy przyznały korporacjom z budżetów państw prywatne sądy ${ }^{8}$. Umowy te mogą ograniczyć możliwości finansowe budżetów, obniżyć standardy społeczne, zmniejszyć bezpieczeństwo żywności ${ }^{9}$, doprowadzić do prywatyzacji i deregulacji usług publicznych. Zastraszane państwa wycofują się $\mathrm{z}$ obrony interesu publicznego, $\mathrm{z}$ regulacji chroniących środowisko naturalne, interesy pracowników, konsumentów, kredytobiorców ${ }^{10}$. Konsekwencją podpisania tego typu umów jest przeniesienie prawa do podejmowania decyzji z poziomu parlamentów, rządów, obywateli na rzecz ekspertów, lobbystów i prawników finansowanych przez międzynarodowy kapitał [Raś 2017]. Może to spowodować prywatyzację sta-

\footnotetext{
${ }^{6} \mathrm{~W}$ negocjacjach brak jest strony społecznej i głosu przedstawicieli większości zainteresowanych państw. Na obrady uczestnikom nie wolno wnosić telefonów, kopiować dokumentów ani nawet robić notatek.

${ }^{7} \mathrm{~W}$ latach 90 . XX w. polskie władze podpisały około 60 bilateralnych umów międzynarodowych zawierających możliwość powołania sadu arbitrażowego, z których jednak, w przeciwieństwie do ww. umów wielostronnych, mogą się wycofać.

${ }^{8}$ Przykładem dowolności wysokości roszczeń i ferowanych wyroków jest sprawa inwestora Abris Capital przeciwko decyzji polskiej Komisji Nadzoru Finansowego. Inwestor zainwestował w Polsce $400 \mathrm{mln}$ zł, a stracił w wyniku sprzedaży inwestycji $20 \mathrm{mln}$ zł. Jednak kwota odszkodowania w pozwie wyniosła 2 mld zł, na tyle bowiem firma oszacowała swoje przyszłe stracone zyski.

${ }^{9}$ W UE jest 1300 substancji zakazanych przy produkcji kosmetyków, w USA - tylko 2. Na 82 pestycydy zabronione w UE, wszystkie są dozwolone w USA. W UE konieczne jest udowodnienie przez przedsiębiorstwa, że wprowadzane środki są bezpieczne; w USA - że szkodzą.

${ }_{10}$ Polska w 2014 r. musiała bronić się przed pozwami korporacji na kwotę ok. 8 mld zł, a w 2015 r. - 10,3 mld zł. W 2009 r. w wyniku sporu PZU - Eureko Polska musiała wypłacić holenderskiej firmie 8 mld zł.
} 
nowienia prawa. Jak pisze Ostapowicz, rządy państw stają się użytecznym instrumentem globalnych firm, banków i rynków [Ostapowicz 2013].

\section{Dyskusja nad kierunkami zmian polityki regulacyjnej państwa - podsumowanie}

Z neoliberalizmem kojarzona jest presja na deregulację i w konsekwencji obniżenie norm chroniących pracowników, konsumentów, środowiska (race to the botton). Jednak nie zawsze tak jest. Niektórzy badacze twierdzą, że w wyniku procesów globalizacji zwiększeniu ulega liczba regulacji prawnych oraz następuje na skutek tego podniesienie standardu życia (race to the top) [Solek 2010]. Często zauważyć też można, że kapitał wybiera miejsca, w których są silne związki zawodowe, duże transfery socjalne, wysoka redystrybucja budżetowa PKB i koszty pracy [Hay 2005, s. 240]. Wysokie koszty pracy mogą być bowiem rekompensowane przez wysoką produktywność oraz stabilność prowadzenia działalności gospodarczej. Wydaje się, że ocena wpływu globalizacji na politykę regulacyjną państwa zależy od poziomu rozwoju gospodarczego i pozycji międzynarodowej kraju, dziedziny gospodarki, rodzaju procesów gospodarczych, rodzaju oraz wielkości podmiotów gospodarczych, których dotyczy analiza. Jak pokazano w tab. 1, np. rośnie liczba regulacji prawnych dotyczących ułatwień dla BIZ, rośnie też liczba przepisów, które m.in. w związku z zagrożeniem terrorystycznym powodują większe możliwości kontrolowania $\mathrm{i}$ inwigilowania społeczeństwa przez państwo. Coraz ściślejszym regulacjom podlega ochrona środowiska i przeciwdziałanie dyskryminacji. Dotyczy to zwłaszcza krajów rozwiniętych. Wzrasta również liczba przepisów prawa międzynarodowego i konieczność ich implementacji przez poszczególne państwa. Tak więc wzrost regulacji i deregulacji zachodzi równocześnie w różnych obszarach życia społeczno-gospodarczego. Powoduje to zmianę sytuacji poszczególnych krajów i grup społecznych.

\section{Literatura}

Buchter H., 2009, Mocarstwo z drzwiami obrotowymi, Die Zeit z 2.07, za: Forum, 2010, nr 30.

Cziomer E., W. Zyblikiewicz, 2007, Zarys współczesnych stosunków międzynarodowych, Wydawnictwo Naukowe PWN, Warszawa.

Galbraith J.K., 2005, Gospodarka niewinnego oszustwa, MT Biznes, Warszawa.

Haliżak E., Kuźniar R., Simonides J. (red.), 2003, Globalizacja a stosunki międzynarodowe, Bydgoszcz - Warszawa.

Hay C., 2005, Globalization's Impact on States, [w:] Ravenhill J. (ed.), Global Political Economy, Oxford University Press, Oxford.

http://www.rynekzdrowia.pl/Finanse-i-zarzadzanie/Rumunia-rzad-wprowadzi-oplaty-za-pobyt-w-szpitalu, 127510,1.html.

http:??biznes.gazetaprawna.pl/artykuly/980577,co-to-jest-ceta-10-rzeczy-których-nie-wiecie-oumowie-ue-kanada. 
Janik M., 2013, Korporacje ważniejsze niż państwa, Dziennik Gazeta Prawna, nr 246/247/248.

Michałowski T., 2008, Międzynarodowy Fundusz Walutowy. Działalność i propozycje reformy, Gdańsk. Oręziak L., 2015, O TTIP: Umowa pomiędzy UE i USA będzie korzystna tylko dla wielkich korporacji,

Gazeta Prawna - Biznes z 4.02.

Ostapowicz B., 2013, Współczesna polityka gospodarcza $w$ warunkach globalizacji, Studia i Prace

Wydziału Nauk Ekonomicznych i Zarządzania, nr 32.

Podgórecki A., 1969, Patologia życia społecznego, PWN, Warszawa.

Polak E., 2009, Globalizacja a zróżnicowanie społeczno-ekonomiczne, Warszawa.

Raś L., 2017, Prof. Oręziak: CETA to pułapka bez możliwości ucieczki, Gazeta Prawna-Biznes z 15.02 Rothkopf D., 2009, Superklasa, Prószyński i S-ka, Warszawa.

Solek A., 2010, Wplyw globalizacji na politykę regulacyjna państwa. Polska wobec procesów globalizacji. Aspekty społeczno-ekonomiczne, PTE, Kraków.

Stiglitz J., 2007, Wizja sprawiedliwej globalizacji, PWN, Warszawa.

Szymański W., 2007, Czy globalizacja musi być irracjonalna, SGH, Warszawa.

UNCTAD, 2001, World Investment Report.

UNCTAD, 2011, World Investment Report.

Wielgosz P., 2004, Opium globalizacji, Wydawnictwo Akademickie Dialog, Warszawa. 